\title{
Potentials for Recycling Residential Solid Waste in Mosul City
}

Obey M. Al- Wattar (Ph.D.)

Assistant Professor - Econ. Dept.

Faculty of Administration and Economics
Sahar A. Mahmood (M.A.)

Assistant Lecturer - Econ. Dept.

Faculty of Administration and Economics

Mosul University- Iraq

janamode2@yahoo.com

\begin{abstract}
Sample survey conducted by the authors in Summer-Autumn 2008 shows that Mosul City generates nearly 620 tons of residential solid waste (RSW) daily. Over 80\% of that quantity is food waste. Since food waste is basically an organic matter, it qualifies as the main input in the production of compost. Thus if it were possible to suitably separate food waste from the rest of RSW generated in Mosul City, it would be in the interest of the Directorate of Mosul Municipality(DMM) to consider acquiring a Compost and Recovery Plant specific to Mosul City, with an initial rated capacity of $\mathbf{1 0 0 0}$ tons of compost a day. However, the biological and mechanical treatment of residential (and commercial) solid waste does not relieve the DMM and the Council of Ninevah Governorate of the responsibility for giving top priority to the establishment of an Integrated Solid Waste Management system, with the sanitary landfill being its center piece.
\end{abstract}

\section{Keywords:}

compost, recycling infrastructure, scavengers, bitter reality, finance, technical assistance, subsidized prices, sanitary landfill . 

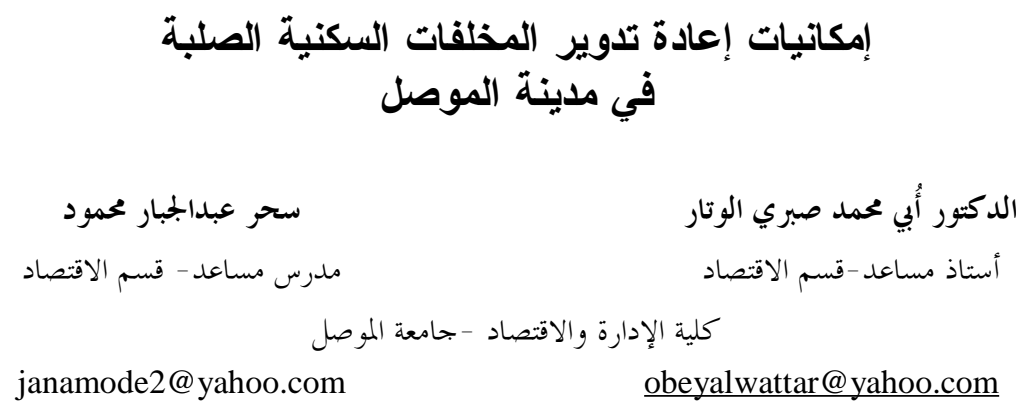

(المستخلص

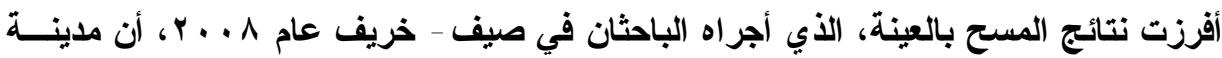

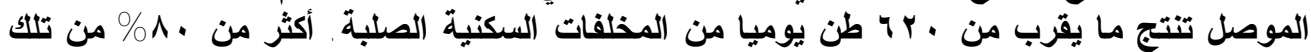

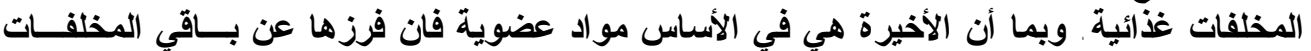

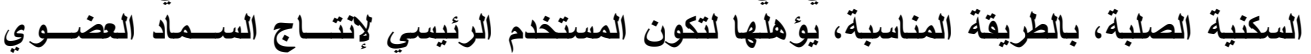

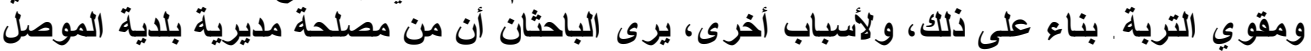

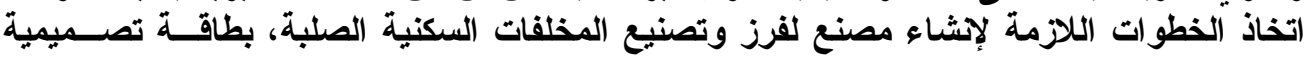

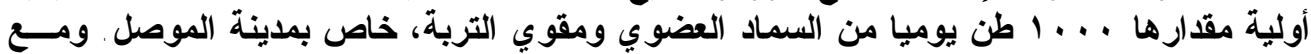

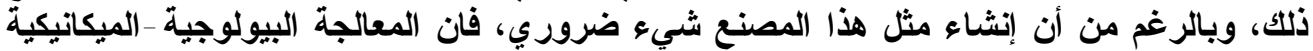

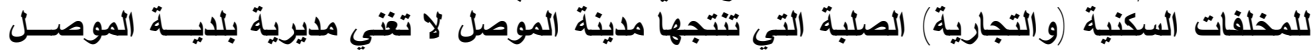

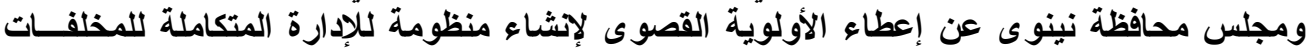

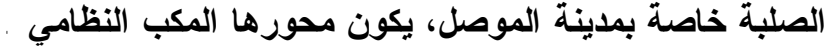

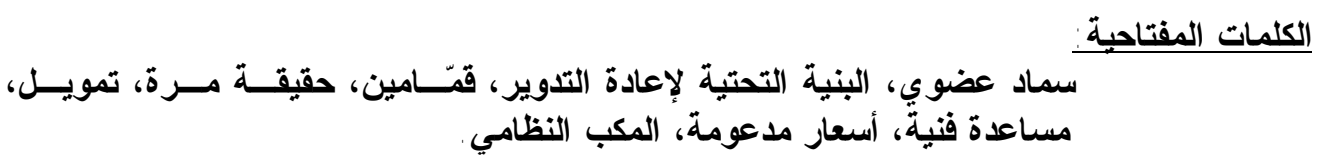

This study is complementary to an earlier one conducted by one of the present authors, few years ago (Al-Wattar, 2006). As with the first, its main thrust is practical. It deals with the quantity and composition of RSW generated in Mosul City on the one hand, and the potentials for its recycling via a Compost and Recovery Plant(CRP), on the other. The authors hope that the present study, though limited in scope, does help the DMM in particular, in its struggle with the growing problems of municipal solid waste (MSW) management in Mosul City. ${ }^{1}$

1 It might be helpful to mention that the estimated population base of Mosul City, as of mid 2008, was around 1.4 million, and expected to grow at an annual rate of $3 \%$, which is the implicit annual growth rate of urban population for Ninevah Governorate. See: COSIT [15], Tables (7/2) A and (7/2) B, and COSIT [16], Table (2/7). 


\section{Section I: Aim of the Study and Research Method}

The aim of this study is to measure the quantity and composition of RSW generated in Mosul City, over Summer- Autumn 2008, and to present the case for the urgent need to build a CRP specific to Mosul City. The research method adopted to achieve that aim was to use a sample survey ${ }^{1}$ for collecting detailed data on RSW generation in Mosul City. The sample size was 65 housing units (mostly houses with a small number of flats) drawn, from Mosul City districts, as close to the stratified-random sampling method as possible. The data set and other information obtained via the sample survey, together with the data on Mosul City population, were then put together and analyzed to arrive via inductive reasoning at a number of conclusions and some recommendations. Before leaving this subsection a word may be said on the step taken by the author to ensure reliability of data collected via the sample survey.

1. The questionnaire ${ }^{2}$ was designed to be as simple as possible. At the same time, it was made to contain enough details on RSW generation by each family, or group of families, living in the same housing unit.

2. The sampled families were those who voluntarily agreed to take part in the sample survey. The authors took pain to explain, to those involved, the aim of the survey and the general aims of the study.

3. Each family was given a questionnaire, a suitable number of plastic bags, a set of baskets for separating RSW, and a hang-scale.

4. The period of data recording was from one to three weeks. The decision on how long to take part in the sample survey was left to the sampled families to decide.

As mentioned earlier, sample size was 65 housing units and the number of questionnaires recovered was the same. Two of the questionnaires were discarded, due to lack of details. These were the steps taken by the authors to ensure reliability of data set upon which the analysis and the conclusions were based.

The next section presents some facts on the extent of municipal solid waste (MSW) pollution in Mosul City in general, and RSW pollution in particular. Section III deals with some conceptual issues on recycling, In section IV, we present generation rates and other data on the quantity and composition of RSW in Mosul City, for the Summer-Autumn 2008. In this section also (section IV) we present the case for building a CRP specific to Mosul City. Section V deals with issues related to the urgent need for building a CRP for Mosul City. The

1. Data set is available on request.

2. See appendix (A) not attached. 
final section contains the main conclusions of the study together with two recommendations.

\section{Section II: Some Facts}

Sample survey shows that over $90 \%$ of RSW generated in Mosul city finds its way either to the "sanitary" landfills ${ }^{1}$, or get dumped in the open space as well as the banks of River Tigris. The remaining $10 \%$ or so, together with a corresponding but unknown part of commercial solid waste (CSW) generated in Mosul City, gets diverted from the waste stream, and the disorderly ${ }^{2}$ landfill disposal sites, to an informal and environmentally harmful recycling system. It is environmentally harmful because scavengers in residential areas for example, who form an integral part of that system, usually tear-off the filled in waste bags, pick e.g. a aluminum beverage cans, then leave...

The working of this primitive recycling system (if it were to be called so) begins with child and adult labour, going around residential and other areas on foot or with their animal-driven carts to buy, or scavenge through rubbish dumps, for recyclable materials (fig.2). Mostly, the materials recovered either way are the following:

a. Aluminum beverage cans, and some other aluminum items.

b. Plastic materials of all types.

c. Copper wires.

d. Dry bread, and other related materials.

e. Some unwanted durables.

The recyclables (in a to c) then shipped (or taken by foot) to small dealers in Mosul City, or its out-skirts. These dealers in turn, either resell the purchased recyclables to wholesale dealers, or shipped them directly to the reprocessing units for transformation into suitable inputs for further processing. As for the purchase prices of small dealer, the authors were able to collect the following data:

1 There are two "sanitary" landfills serving Mosul City. The first is Al-Gogjali landfill, located some 13 kilometers east of River Tigris. The second is Al-Sahaji landfill, located some 12 kilometers to the west of River Tigris. Both landfills are not operational at present (Dec. 2009), due to security reasons, mainly. The only "temporary" operational landfill now is the Al- Arabi. Both, Al-Arabi and Al-Gogjali landfills were visited by Dr. O.M Al-Wattar on Saturday 9/8/2008. (The authors would like to thank the Assistant Director of East Tigris Services Section of the DMM for facilitating the visit by providing the transportation means and a driver).

2 On the construction and operation of orderly (or sanitary) landfills, see: Tchobanoglous et al. [9], PP. 361-491. 


\begin{tabular}{|c|c|c|}
\hline \multicolumn{3}{|c|}{$\begin{array}{c}\text { Table } 1 \\
\text { Purchase Prices of Small Dealers with Recyclables, } \\
\text { Mosul City, April, } 2010\end{array}$} \\
\hline $\mathbf{S . N}$ & Recyclable item & Price per kilogram (US\$) \\
\hline 1. & Aluminum cans & $0.42-0.63$ \\
\hline 2. & Other aluminum items : & \\
\hline & - light $^{\mathrm{a}}$ & $0.63-0.71$ \\
\hline & - heavy & $0.38-0.59$ \\
\hline 3. & Plastic materials : & \\
\hline & - chairs and similar & 0.17 \\
\hline & - others & 0.08 \\
\hline 4. & Copper $^{\mathrm{c}}$ & $3.78-5.05$ \\
\hline 5. & Dry bread & 0.11 \\
\hline
\end{tabular}

a. Aluminum utensils, wires and similar items.

b. Scrap items. (from motorcycles, cars, vans, etc.).

c. Wires mainly.

Source: Data collected by the authors from dealers with recyclables. (on Saturday 17 April 2010).

To the authors knowledge, no reliable official data or an empirical study exist, at Mosul University or elsewhere, on the actual size of the recycling sector in Mosul City, nor on the types and quality of its finished products. As for the facts on MSW pollution in Mosul City in general, and RSW pollution in particular, figures (1-6) convey a good deal of the bitter reality in the city. 


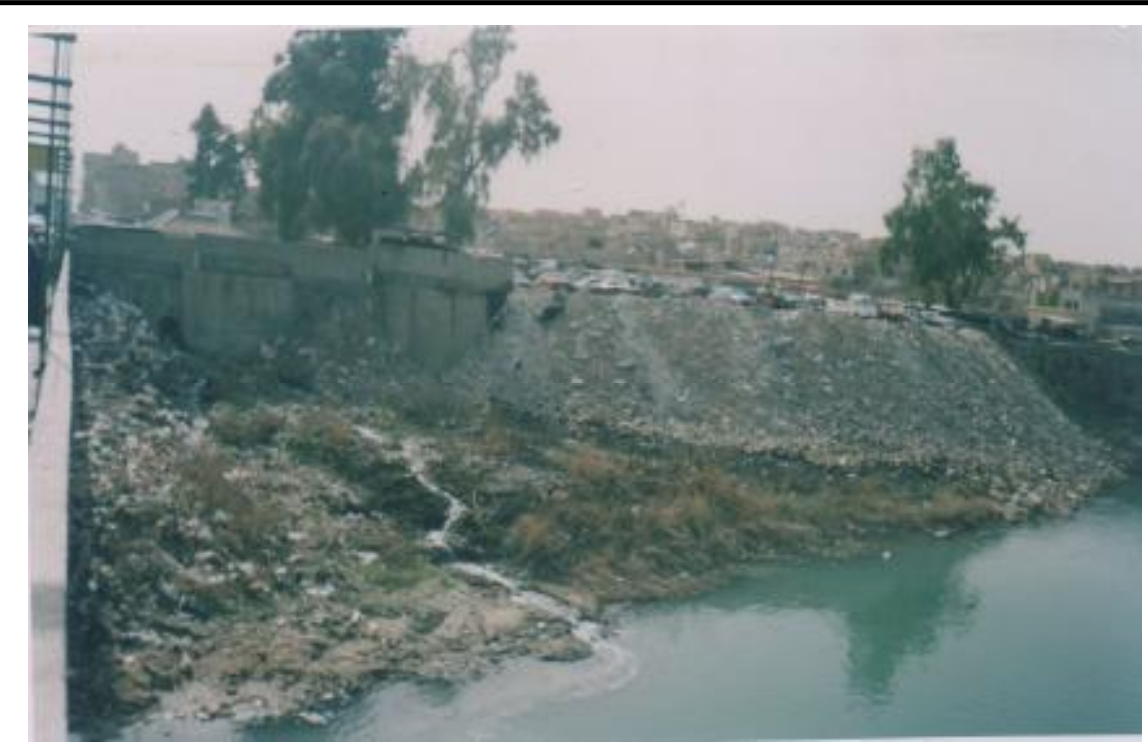

Figure 1

Mosul City : Solid waste discharged at the bank of River Tigris close to Nineveh Bridge (photo taken on 24-3-2008)

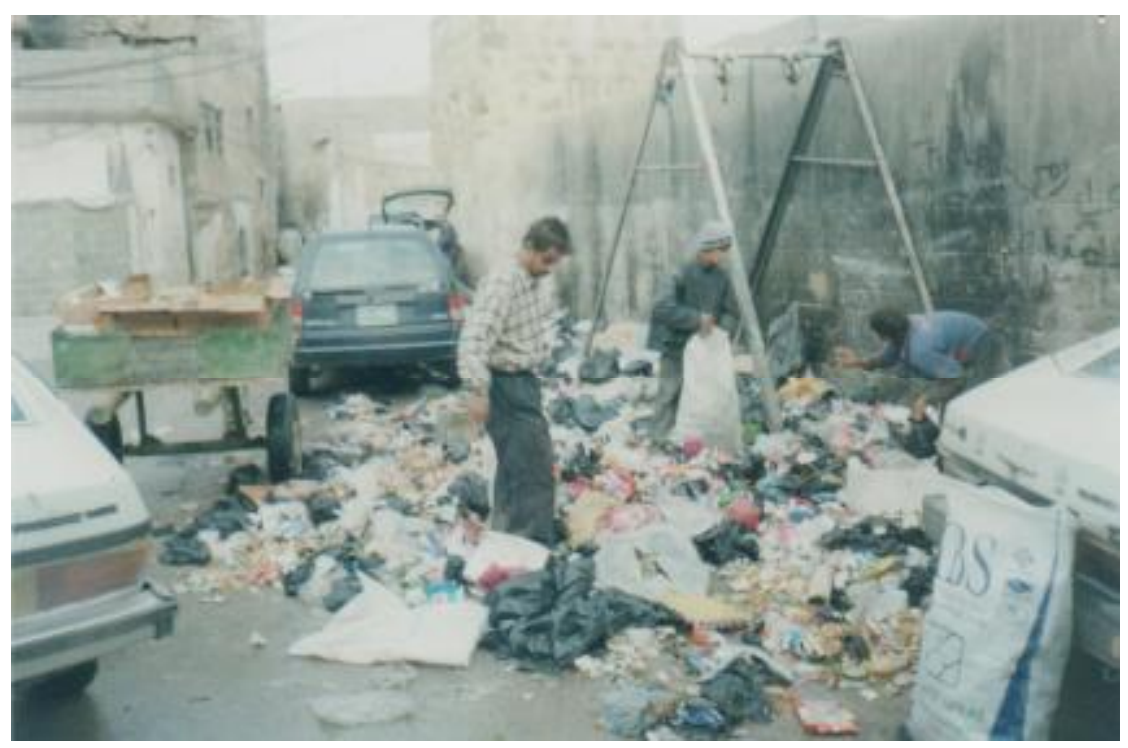

Fig.2

Mosul inner- city, a dump and scavengers in action (photo taken on 26-12-2008) 
Al- Wattar \& Mahmood [15]

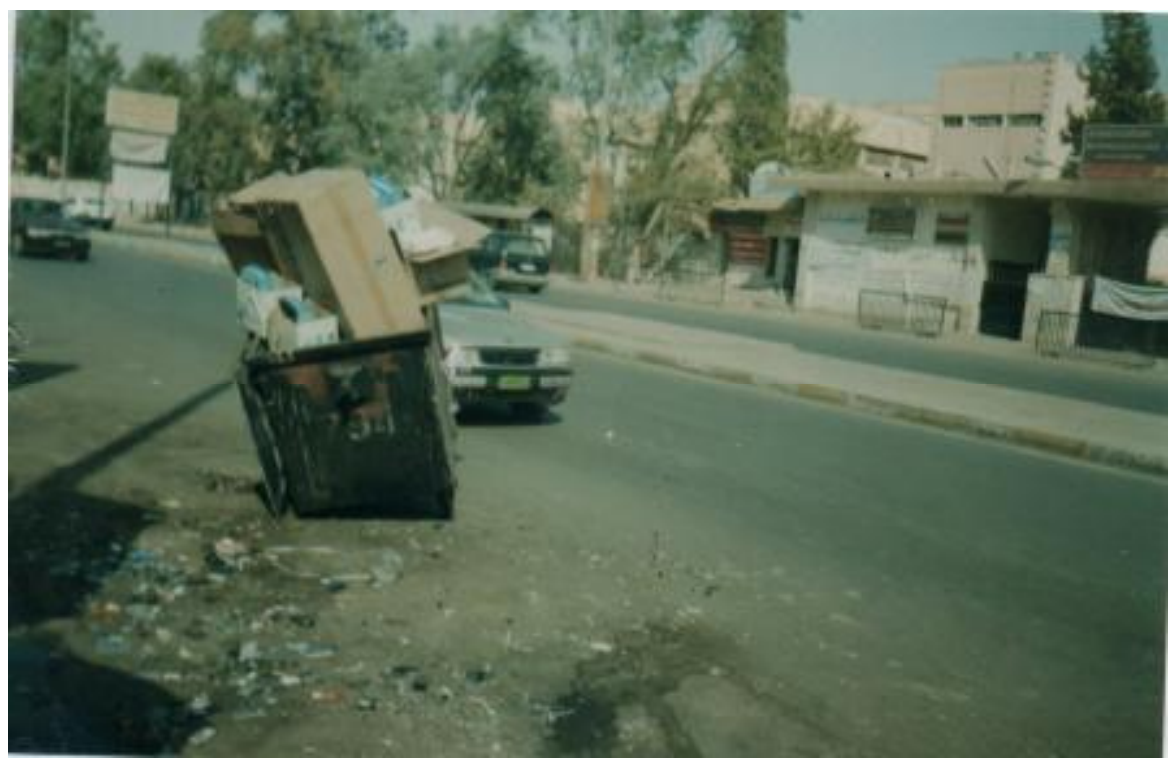

Fig 3

Mosul City, university area. A container loaded with uncompacted cardboard boxes (photo taken on 17-10-2009)

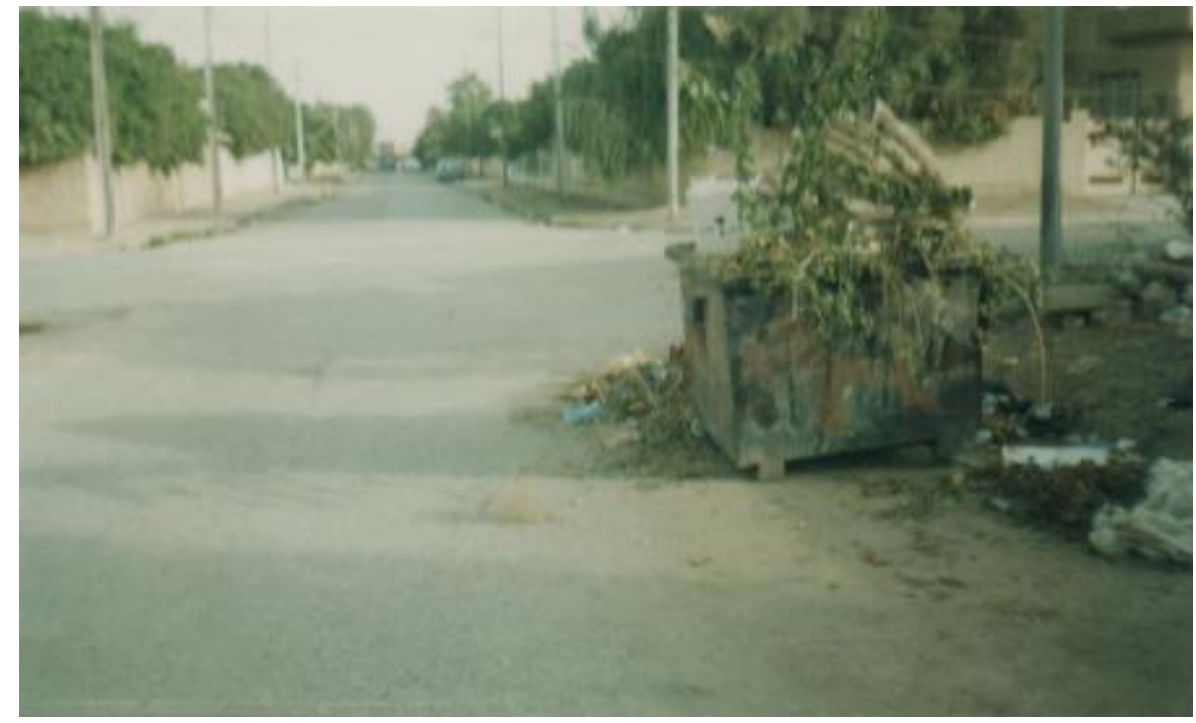

Fig 4

Mosul City, Al- Dobbat district, yard west placed in a community container (photo taken in mid October 2009) 


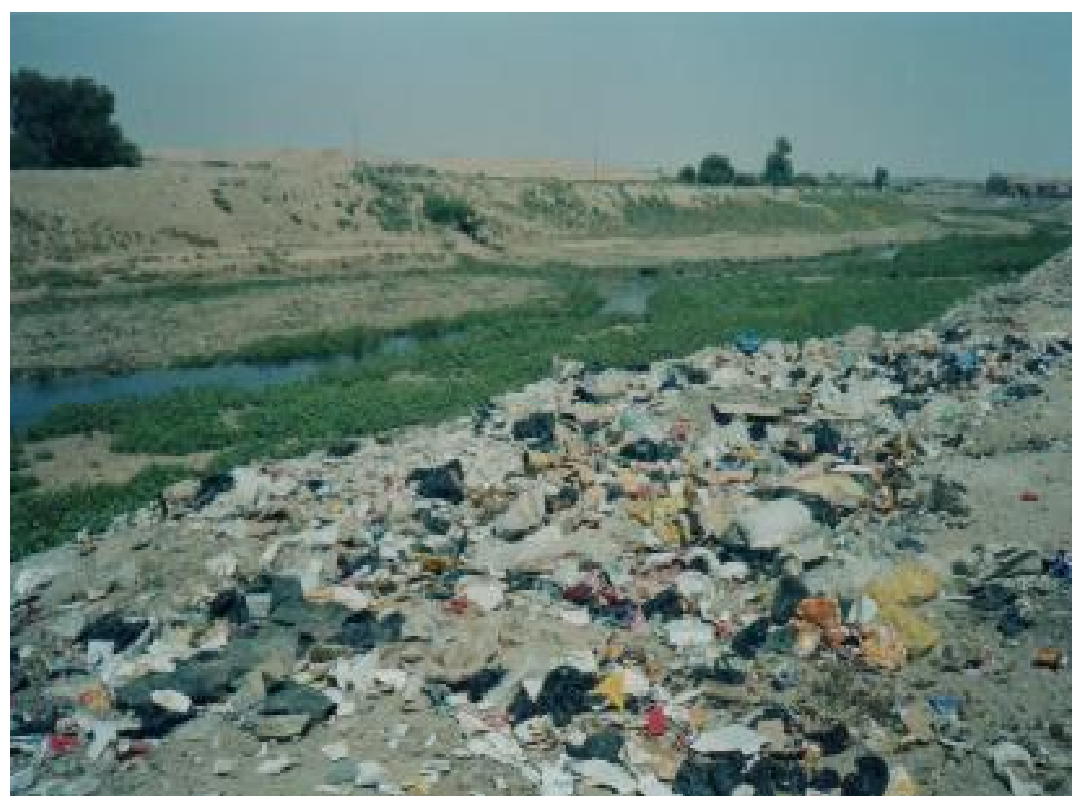

Fig 5

Mosul City, Al- Soways district. A dump in the open space close to River Khoser (photo taken on 26-7-2008)

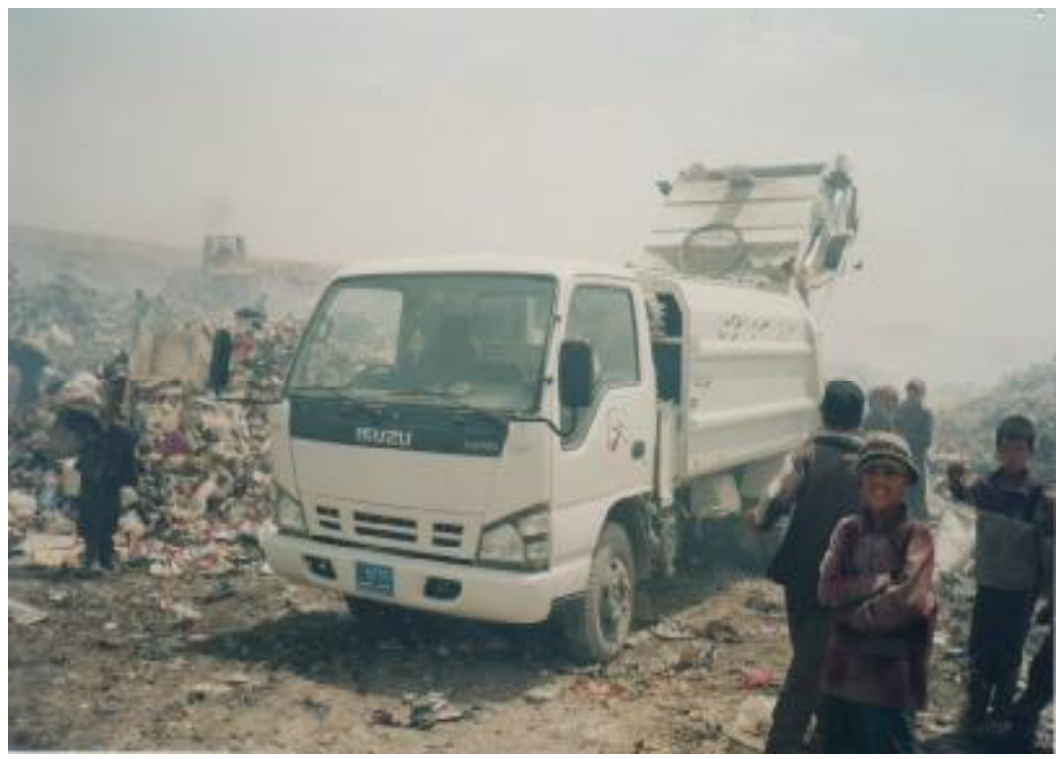

Fig 6

An Izuzu hydraulic compacter truck before leaving Al-Gogjali landfill, Mosul (photo taken on 9-8-2008) 
These figures, together with the content of Table 3, show (among other things) that district containers can be "home" to uncompacted cardboard boxes, yard waste, food waste, etc. Moreover, the rapidly growing city population, running at an annual rate of $3 \%^{1}$, fiscal constraints facing the DMM, and uncooperative public, present formidable challenges to the DMM. Needless to say that a meaningful recycling strategy can not be adopted by the DMM without a minimum degree of cooperation of the public, on the one hand, and the active involvement of Mosul University and the Local Government (LG) represented by the Council of Ninevah Governorate $(\mathrm{CNG})$, on the other.

\section{Section III: The Concept of Recycling and Recycling Infrastructure}

Recycling may be generally defined as "...recovering and reintroducing materials into the system..."(Tietenberg, 2001, 364). It constitutes the second highest rank in the hierarchy of Integrated Solid West Management (ISWM), and involves the following sequence (Tchobanoglous et al.,1993, 16)

a. Separation and collection of waste materials.

b. Preparation of these materials for reuse, reprocessing, and remanufacture; and

c. The reuse, reprocessing, and remanufacture of those materials.

Needless to say that recycling is a major factor in helping to reduce demand for virgin resources on the one hand, and the amount of solid waste requiring disposal by landfilling, on the other. ${ }^{2}$ As for recycling infrastructure, its main components ${ }^{3}$ are as follows :

a. Transportation fleet such as waste collection vehicles, to collect solid waste from e.g. curb- side to the waste CRP.

b. Intermediate processing units.

c. Manufacturing plants, and

d. Storage facilities.

These key elements of recycling infrastructure must be given special attention by the DMM and LG if a meaningful recycling strategy were to be adopted and a relevant strategic plan were to be put into practice. No doubt, investment in recycling infrastructure is a necessary condition for the adoption of recycling strategy on the part of the DMM and the LG.

1 See note 1 , page 10 .

2. For details see e. g. Tchobanoglous et al. [9] , P. 16 ; Fortini [2], P. 16.

3 Physical capital assets, including animal carts, which belong to private dealers and garbage collectors (zabballeen) are an important element of recycling infrastructure in developing countries. See : WHO[23], especially PP. 27-30, 42, and PP. 64-65. 


\section{Section IV: Quantities to be Recycled and the Need for a Compost and Recovery} Plant

We turn now to the measurement of the (growing) quantity of residential solid waste generated in Mosul City and its component composition. The set of questions which may be addressed in this respect are the following:

1. What is the quantity and composition of RSW generated in Mosul City today? and, is there any potential for recycling its main components?

2. What infrastructure is currently available in Mosul City, which may be considered useful for recycling the main components RSW generated in the city?

3. Assuming that the needed finance ${ }^{1}$ for the construction of CRP, together with other necessary infrastructure required for its efficient operations, were made available, would there be a market (domestic or otherwise) for the potential products of the CRP if the latter were to be created one way or another?

The answers to these questions determine what should be done next, if a meaningful recycling strategy were to be adopted by DMM and LG in particular. To supply an answer to the first question, we first need to find out the generation rates for the main categories of the RSW generated in Mosul City. Using the sample survey data, together with the relevant formulae of appendix $\mathbf{B}$, it was possible to obtain the following generation rates in Mosul City (Table 2):

Table 2

Generation Rates for the Main Categories of RSW, Mosul City (Summer- Autumn 2008)

\begin{tabular}{|c|l|c|}
\hline S.N. & \multicolumn{1}{|c|}{ RSW category } & Generation rate $^{\text {a }}$ \\
\hline 1 & Food waste & 0.3681 \\
\hline 2 & Paper and cardboard & 0.0136 \\
\hline 3 & Glass & 0.0119 \\
\hline 4 & Plastic and rubber & 0.0108 \\
\hline 5 & Metal $^{\text {b }}$ & 0.0103 \\
\hline 6 & Other materials & 0.0264 \\
\hline 7 & All & 0.4411 \\
\hline
\end{tabular}

a. kilogram per capita per day(kg/cap/d). b. Including aluminum beverage cans. Source: Primary data applied to the relevant formula of Appendix B (available on request).

In the table above, food waste generation rate is the highest $(0.3681$ $\mathrm{kg} / \mathrm{cap} / \mathrm{d}$ ), followed by the much lower generation rates for paper and cardboard $(0.0136 \mathrm{~kg} / \mathrm{cap} / \mathrm{d})$, and glass $(0.0119 \mathrm{~kg} / \mathrm{cap} / \mathrm{d})$, etc.

1 In more than one meeting with the Director General and other senior officials of the DMM, held in 2009, it was clear to the authors that the DMM is in urgent need for the financial and technical assistance required for the development and construction of ISWM system units specific to Mosul City. See also: McCarthy [5], PP.2-7. 
Secondly, given the generation rates for the main categories for RSW (Table 1) together with an estimated city population of 1.4 millions (mid 2008), it was possible to work out the total daily quantity of RSW generated in Mosul City, together with its component composition (Table 3).

Table 3

Total Daily Quantities of RSW Generated in Mosul City (Summer- Autumn 2008)

\begin{tabular}{|c|l|c|c|}
\hline S.N & \multicolumn{1}{|c|}{ RSW categories } & $\begin{array}{c}\text { Quantity of RSW } \\
\text { (tons) }\end{array}$ & $\begin{array}{c}\text { Composition } \\
(\mathbf{\%})\end{array}$ \\
\hline 1 & Food waste & 515.3 & 83.5 \\
\hline 2 & Paper and cardboard & 19.0 & 3.1 \\
\hline 3 & Glass & 16.7 & 2.7 \\
\hline 4 & Plastic and rubber & 15.1 & 2.5 \\
\hline 5 & Metal & 14.4 & 2.3 \\
\hline 6 & Other materials & 37.0 & 6.0 \\
\hline 7 & Total & 617.5 & $100.0^{\mathrm{a}}$ \\
\hline
\end{tabular}

a. Close to 100.0 due to rounding.

Source: Table (1) coupled with a city population base of 1.4 millions (see note 1, page 10).

Table 3 shows that total daily quantity of RSW generated in Mosul City (Summer- Autumns 2008) ${ }^{1}$ was estimated at nearly 620 tons. Over $80 \%{ }^{2}$ of that quantity (a little over 500 tons) is food waste. Since food waste is an organic matter, it qualifies for being the main input in the production of compost. Thus, if it were possible to suitably separate food waste - one way or another - from total RSW generated daily in the city, it would be possible for the DMM to consider acquiring a CRP specific to Mosul City. The plant may be similar to ISTAÇ compost and recovery plant ${ }^{3}$ of Istanbul Metropolitan Municipality

1 In Table (1), the over all Summer-Autumn 2008 RSW generation rate in Mosul City was estimated at $0.441 \mathrm{~kg} / \mathrm{cap} / \mathrm{d}$. The corresponding rate for the winter season may be estimated at $0.30 \mathrm{~kg} / \mathrm{cap} / \mathrm{d}$. See Al-Wattar [11],Table (3); See also : Yousif [13],P.52 and Table (5-1); Cointreau- Levine and Gopalan [ 1 ] , Table A1.1 .

2 In Yousif [13], Table (4-3), the corresponding number is $81 \%$. By comparison, food waste makes $69.8 \%$ of RSW in Sale (Morocco); and an overall mean value of $61.3 \%$ in Jordan. See: WHO [23], Tables ( 8 \& 11); See also: Tchobanoglous et al [9], Table (3-5). It may be mentioned that in Al-Rawi study [8] which contains data on the quantity and composition of RSW in Mosul City ( with food waste nearly $68.2 \%$ of the total), the formula used to work out generation rates for the component composition of RSW generated in Mosul City does not produce correct results. See: Al-Rawi[8], P. 41. The authors think that the formula derived in Appendix B (available on request) does produce the required results.

3 See: IMM [ 19 ], P.27. 
(IMM), in the western section of Istanbul (Turkey).The rated capacity of the later plant is 1000 tons of compost a day. ${ }^{1}$

Therefore, it seems that a quantity of RSW generated in Mosul City today (Dec. 2009) of nearly 620 tons a day, pending on proper separation one way or another, justifies giving serious consideration by the DMM to the idea of acquiring a CRP with an initial rated capacity of 1000 tons of compost output per day .

As for the other elements of infrastructure needed for the efficient operation of the would be CRP, the authors think that with some reorganization, the DMM can use part of its current collection fleet together with its maintenance capacity to bring residential (and commercial for that matter) solid waste to the CRP. Table (4) shows some details about the collection fleet owned by the DMM as of mid August 2009.

Table 4

Collection Fleet Owned by the Directorate of Mosul Municipality, Mid August , 2009

\begin{tabular}{|c|l|c|}
\hline S.N & Type of Vehicle & Number \\
\hline 1 & Rear loading hydraulic compactor truck : & \\
\hline & -6 tons capacity & 34 \\
\hline & -3.5 tons capacity & 11 \\
\hline 2 & Tractor with open (tilt) trailer & 97 \\
\hline 3 & Dumper & 15 \\
\hline 4 & Total & 157 \\
\hline
\end{tabular}

Source: DMM, The Organizational Structure of Mosul Municipality, Manual of Tasks, 20 August 2009.

Let us move now to addressing the third question raised on page (18). Supposing that the DMM were able to obtain the finance ${ }^{2}$ needed to build the CRP, together with the necessary technical expertise required for its construction and efficient operation, would there be a market for its potential products ? The answer to this important question brings one to the field of product market for recycled material and the associated issues of sales expectation and uncertainty (Leverenz and Kreith, 2002, 1-17). In addressing this question, the following points may be taken into consideration:

1 Among other products of this CRP is Refuse Derived Fuel (RDF), aluminum bales, and cardboard bales. See : IMM , Ibid. , PP. 28-29.

2 See note 1 , page 18 . 
a. The compost produced in the would-be CRP should be of comparable quality with the alternative compost produced by e.g. ISTAÇ compost plants of the IMM, Turkey.

b. The compost, together with the other potential products jointly produced with it, are expected to be sold at a subsidized price, for a certain period of time at least, depending on the prevailing (domestic) market conditions for compost.

c. In Iraq, fertilizer production 2009 was 237,898 tons , which is less than $25 \%$ of the quantity of fertilizer produced in 1992 (986000 tons) ${ }^{1}$.

d. The Iraqi central government have taken the initiative for conducting a large-scale agricultural development, on a national level. ${ }^{2}$

Given these points, it may be concluded that the DMM should give serious consideration to the idea of building a CRP specific to Mosul City, with an initial rated capacity of 1000 tons of compost a day. As for the demand for the other finished products of the CRP, the authors think that the local market would not be incapable of absorbing those products, if they were to be offered at a sufficiently low subsidized price.

\section{Issues Related to the Need for Recycling RSW in Mosul City :}

The facts, and the argument presented in the last two sections of the present study lead to a number of questions among which are the following two: Do we $^{3}$ carry on with the present practices of the disorderly disposal of residential (and commercial) solid waste generated in Mosul City, or act now towards its recycling? Secondly, even if it were possible to adopt a meaningful recycling strategy on the part of the DMM and the LG, does the Mechanical/ Biological Treatment (MBT) of residential (and commercial) solid waste relieve Mosul City from the need for ISWM system, with the sanitary landfill being its centre piece ?

No doubt, the answer to the first question must be a positive one. The DMM and the Local Government, in particular, need to act now...As for the answer to the second question, logic and experience (e.g. from ISWM in Rome ${ }^{4}$ ) dictate that that BMT of the residential and commercial solid waste (among others) is no more than an intermediate stage within ISWM. If this were the case, then the BMT would not relieve the DMM and the CNG of the responsibility for giving serious attention to the urgent need for the development, construction and the

1 See: CSO[17], Table (3/7), and CSO[14], Table (3/7), respectively .

2 For example, out of total investment allocations of $\$ 186$ billions (for the plan period 20102014), 9.5\% was allocated to the development of the agricultural sector in Iraq.

See: Republic of Iraq[18], Part I, PP.3-5 .

3 That is: The DMM, LG represented by the CNG, and Mosul University .

4 See : Fortini [2 ],P.16. 
efficient operation of an ISWM system specific to Mosul City, in which the sanitary landfill plays a pivotal role.

\section{Section V: Can Mosul City Affords Further Delay in Adopting Recycling Strategy ?}

During the period 1980-2003, Iraq had to go through three external wars and crippling "economic" embargo. ${ }^{1}$ Although Iraq was ( and still is, we may say) an oil rich ${ }^{2}$ country, financing the war operations and the survival of the pre $9^{\text {th }}$ April 2003 Baath regime were given top priority. ${ }^{3}$ As a result, all meaningful developmental efforts and environmental protection schemes were of no concern to the ruling oligarchy. This in turn, made the concept of ISWM and the establishment of ISWM system in Mosul City (and the other Iraqi cities as well) a luxury affair... After April 2003, the city had a chance to have an ISWM through the various forms of help offered by the Collation Forces (CF), the Research Triangle Institute (RTI) and the UNDP in particular. Unfortunately, the deterioration of the security situation during 2005-2007 forced the RTI and the UNDP to leave Mosul City for Duhok, in Iraqi Kurdistan.

After 2007, the security situation in the city, and in Nineveh Governorate in general, greatly improved. However, the DMM, with its limited financial resources, lack of qualified technical staff and poor infrastructure, is struggling to maintain a functioning solid waste collection system. Needless to say that MSW in general, and RSW in particular, dramatically increased since 2003, and continues to increase due to rapid population growth and the government effort aimed at, among other things, creating (directly and indirectly) job opportunities for the unemployed. ${ }^{4}$ These developments made things more difficult for the DMM, as far as municipal solid waste management in Mosul City is concerned. On the other hand, there are four positive elements, at least, which stand in support of the adoption (by the DMM in particular) of ISWM in Mosul City, including of course recycling strategy:

1. Since MBT is no more than an intermediate stage within ISWM (Fortini, 2009,P. 16; Thcobanoglous et al.,1993,90-97) the adoption of recycling

1 The embargo was imposed on Iraq according to Security Council resolution No. 661 for 1990, as a result of the well known invasion of the State of Kuwait, by the doomed Iraqi Baath regime, on 2nd August 1990. The lifting of that " economic embargo" was based on Security Council resolution No. 1483 for 2003.

2 In terms of proven crude oil reserves, Iraq is the third largest country in OPEC. See: OPEC [22], Table 33, and OPEC[21], Table 1, P.27 .

3 For more details see e.g. Republic of Iraq [18], Part I, P.5; Penrose and Penrose [7], PP. 537538 .

4 See: McCarthy [6], PP.2-3; McCarthy [5], P.1 ; Al-Wattar [12], especially Tables 1-4. 
strategy by the DMM and the Council of Nineveh Governorate (CNG) implies the necessity for the development, construction and the efficient operation of ISWM system in Mosul City.

2. The Kirkuk City experiment, i.e. the creation of an integrated solid waste management system in Kirkuk City (north east of Iraq), which was officially opened and entered into operations on the $2^{\text {nd }}$ July 2008, is an invaluable example for the DMM and the LG represented by the CNG to adopt and copy, on double scale. It is "on double scale", because the Kirkuk City sanitary landfill (developed, constructed and prepared for operation by the U.S. Army Corps of Engineers, the CERP, US Aid, RTI, others) was designed to serve a city with a population base of 700,000 inhabitants (McCarthy, 2008, 4-5) which is nearly half the (mid 2008) estimated population of Mosul City. ${ }^{1}$

3. The adoption by the Iraqi government of the principle of decentralization in the management of the development process, gave greater role to Local Governments in (among other things) the determination of local developmental needs. To translate this principle into developmental allocations, the central government devoted $12.5 \%$ (i.e. $\$ 12.5$ billions) of the total investment expenditures of the National Development Plan 20102014 to the so-called "Regional Development Program". ${ }^{2}$ The share of $\mathrm{NG}$ in the program over the plan period is $11.5 \% .^{3}$ As far as financing the development and construction of ISWM system in Mosul City (sanitary landfills and transfer stations in particular) are concerned,the adoption of this principle is an important step forward. It enables the DMM (and the $\mathrm{CNG}$ ) to move faster towards the adoption ISWM , including recycling strategy.

4. In addition to the financial and technical assistance which was extended to the DMM and LG by the US army corps of engineers, the RTI and the UNDP, Turkish government has extended a helpful hand to the DMM in the field of ISWM. ${ }^{4}$

1 See note 1 , page 10 .

2 National Development Plan 2010-2014 in: Republic of Iraq [18], P. 4, 17-18.

3 Ibid, Part II, Table on investment allocations of the Regional Development Program according to governorates.

4 It may be mentioned that Istanbul Metropolitan Municipality (IMM) sponsored, and implemented via ISTAC (of IMM), an intensive training program in the field of ISWM attended by a selected number of DMM employees and Mosul University teaching staff, over the period 24-28 November 2008. The practical part of the program included visits to a transfer station, a modern landfill, and a compost and recovery plant. All facilities are located in the European side of Istanbul . See: IMM [20]. 
5. In the National Development Plan 2010-2014, the Central Government allocated $9.5 \%$ of total investment allocations to capacity expansion, and to the sustainable development of the agricultural sector.

The authors think that the five positive points taken together mean that the DMM and the CNG both can move forward towards the adoption of ISWM principle in Mosul City, including a meaningful recycling strategy .

\section{Section VI: Conclusions and Recommendations}

\section{Conclusions}

The main conclusions to which this exploratory work leads are the following:

a. As with the other components of MSW, the curb-side RSW generated in Mosul City is commingled. It is being disposed of by the DMM in an ad hoc manner (Fig.6). Over 90\% of RSW finds it way, via a fleet of (157) collection vehicles of various capacities, to the unregulated Al-Arabi landfill, less than three miles from Mosul University. The other two landfills (Al-Gogjali and Al-Sahagi landfills) are currently (Dec. 2009) not operational for security reasons mainly. Any additional efforts, made by the DMM, aimed at a complete clean up of residential (and commercial) solid waste materials within Mosul City would be no more than taking the same solid waste to one of the three unregulated landfills mentioned earlier. No environmentally safe recycling activity exists in Mosul City and rapid population growth, running at an annual rate of $3 \%$, makes things worse...

b. Sample survey conducted by the authors over Summer-Autumn 2008 shows that Mosul City generates nearly 620 tons of RSW daily, over $80 \%$ of which is food waste. Paper and cardboard materials makes $3.1 \%$ of that total, while the share of glass is $2.7 \%$, plastic and rubber materials is $2.5 \%$ (See table 3). Since food waste is basically an organic matter, it qualifies for being the main input in the production of compost. Thus, if it were possible to suitably separate food waste from the total - commingled - RSW generated daily in the city, it would be in the interest of the DMM to consider acquiring a CRP specific to Mosul City. The initial rated capacity of the plant may be 1000 tons of compost a day, taking into consideration the (so far unknown) quantity of commercial solid waste generated in the city.

c. Acquiring a CRP, one way or another, by the DMM and running the plant at reasonable degree of capacity utilization and operational efficiency implies the adoption of recycling strategy by the DMM and the LG represented by the CNG. This, in turn, implies the creation of an ISWM system, the center piece of which, of course, is the sanitary landfill. In this 
respect, the Kirkuk experiment in the development and construction of an environmentally engineered landfill and two transfer stations, is of immense benefit to the DMM and the CNG.

d. The DMM, or any other organization which may be responsible for the operational side of the would be CRP, does not need to worry about marketing its products- compost in particular. The justifications for that were given on page 10-12.

e. The authors think that without external assistance (financial and technical), the DMM alone cannot embark upon such a huge project as the development, construction, and operation of ISWM system designed to serve a city with population base of 1.4 millions, and growing at an annual rate of $3 \%$ or more.

These are the main conclusions to which this study leads.

\section{Recommendations}

The above set of conclusions warrant a number of recommendations, among which are the following two:

\section{Recommendation I}

Since the development and construction of any CRP can not be viewed in isolation of an ISWM system, which does not exist in Mosul City today (December 2009), the authors strongly recommend that the CNG, in consultation with the DMM approaches the US Army Corps of Engineer, the RTI, and USAID, requesting their financial and technical assistance in the development and construction of the following SWM units, in Mosul City:

1. A CRP with a rated capacity of 1000 tons of compost a day. The location of the plant may be determined by ISWM experts.

2. Two sanitary landfills, each may be modeled on the Kirkuk landfill project, which was completed on February 2008. The two landfills may be served by two transfer stations each. The authors think that the Kirkuk sanitary landfill, together with the two supporting transfer stations, are an excellent examples of what might be achieved in Mosul City, in the field of ISWM.

\section{Recommendation II}

The present work, though limited in scope, does provide the DMM (and others) with some basic data on the quantity and composition of RSW in Mosul City. However, the DMM is still in desperate need for basic and reliable data, including data on the quantity and composition of residential and commercial solid waste generation in Mosul City. To the author's knowledge, no such 
data exist, whether at Mosul University (in any form) or elsewhere. To fill in this data gap, the authors strongly recommend that Mosul University takes the initiative in that direction, without further delay.

We hope that this work, and the two recommendations in particular, will be given due consideration by the parties concerned.

\section{Acknowledgments}

The authors are grateful to Khawla Khalid for her helpful comments, and to each of the families who agreed to take part in the sample survey, and to an anonymous referees, without implicating any in the views and errors of this work.

\section{References}

1. Cointreau- Levine, S. and Gopalan, P. Guidance Pack: Private Sector Participation in Solid Waste Management (London: Intermediate Technology Publications, 2000).

2. Fortini, D. "Rectifying a West Crisis", in: Waste Management World, International Solid Waste Association (ISWA), March-April 2009 (www.waste-management.world.com) .

3. Larson, R. and Farber, B. Elementary Statistics (New Jersey: Prentice- Hall, 2000).

4 Leverenz , H. and Kreith, F. "Market and Products for Recycled Material", in: Tchobanoglous, G. and Krieth, F. Handbook of Solid Waste Management, Second Edition (New York : McGraw-Hill, 2002).

5. McCarthy, B. "Kirkuk City Solid Waste Management Program: Developments, Construction and Operations", RTI International/ Kirkuk Provincial Reconstruction Team, 1 November, 2008.

6. McCarthy, B. Iraq National Solid Waste Management Symposium, $15^{\text {th }}-17^{\text {th }}$ August 2008,Sulaymaniyah, Iraq.( The conference was organized by : The Ministry of Municipalities and Public Works/Iraq, RTI International, USAID, others).

7. Penrose, E. and Penrose, E.F. Iraq: International Relations and National Development (London: Ernest Benn, 1978) .

8. Al-Rawi, S. M. Selection, Design and Management: Sanitary Landfill Site(s) for Mosul City, Center of Environmental Research and Pollution Control, Mosul University (Iraq),2007 .

9.Tchobanoglous, G. et al. Integrated Solid Waste Management (London: McGraw-hill, 1993).

10. Tietenberg, T. Environmental Economics Policy, Second Edition (London: AddisonWesley, 2001).

11.Al-Wattar,O.M. " Population, Residential Solid Waste Generation and Containers Needed in Mosul City", Journal of Solid Waste Technology and Management,Vol.32, No.2. May 2006.

12. Al-Wattar, O. M." Population Growth, Urban Expansion and the Quantity of Residential and Commercial Solid Waste in Mosul City 1957-2006", Tanmiat Al-Rafidain, Faculty of Administration and Economics, Mosul University (Iraq), Vol.33, No.102, 2011, (in Arabic).

13.Yousif,W.F. Management and Disposal of Residential Solid Waste in Mosul City, M.Sc. Dissertation, Mosul University, Iraq.1988(in Arabic).

14. Republic of Iraq, Central Statistical Organization (CSO),Annual Abstract of Statistics 1994 (Baghdad :CSO Printing Press, 1995). 
15. -----------, Central Organization for Statistics and Information Technology (COSIT), Annual Statistical Abstract 2005-2006 (Baghdad: Al-Essami Printing Press,2007) . (www.cosit.gov.iq).

16. -----------,(COSIT), Annual Statistical Abstract 2007 (Baghdad: CSOIT Printing Press, 2008).

17. -------------,(CSO), Annual Statistical Abstract 2008-2009 (Baghdad: CSOIT Printing Press, 2010).

18. ---------, Ministry of Planning , National Development Plan 2010-2014 , Plan Document ( Baghdad: Ministry of Planning publications,2009).

19. Istanbul Metropolitan Municipality(IMM) ,Istanbul Environmental Protection and Waste Materials Industry and Trade Co.(ISTAC), Environmental Management, 2008. (www.istac.com.tr).

20 .---------, Entegre Kati Atik Yönetmi Eğitimi , 24-28 Kasim 2008 (Irak Hyeti).

21. Organization of Petroleum Exporting Countries(OPEC), Annual Report 1983 (Vienna: OPEC Secretariat, 1983).

22.------------, Annual Statistical Bulletin 2008 (Vienna: OPEC Secretariat, 2009).

23. World Health Organization (WHO), Solid Waste Management in Some Countries in the Eastern Mediterranean Region, CEHA Document No: Special Studies SS - 4, Amman, 1995. 